\title{
Derrida's Secret and Symptom: A Certain Impossible Possibility of Writing the Event ${ }^{1}$
}

\author{
Kyle Kinaschuk
}

"There is, in every event, secret and symptomatology."

- Jacques Derrida, "A Certain Impossible Possibility of Saying the Event"

"Repetition and first time: this is perhaps the question of the event as the question of the ghost." - Jacques Derrida, Spectres of Marx

Is it not questionable to begin with a question?

In this paper, I attempt to conceptualize the event through Derrida's late lecture "A Certain Impossible Possibility of Saying the Event,"2 which he presented "spontaneously" at the Canadian Centre of Architecture in Montreal on April 1st 1997. Furthermore, I will analyze how a certain conception of the event emerges out of the conversations among Derrida, J.L. Austin, and John Searle, especially considering the text that "started" the muchdiscussed debate between Derrida and the Anglo-American speech act theorists: Austin's How to Do Things With Words. I will deploy Derrida's "concepts" of iterability and the perverformative to think through the ways the event, if it can be written that it exists, is undoubtedly beyond the categories of the performative and constative; however, recourse to the many impossible-possible aporias that populate Derrida's late texts such as the decision, forgiveness, and invention will be necessary to understand this difficult position. I will relate the symptom and the secret, then, to the event through an interrogation of "verticality" while analyzing the event's capacity to disrupt established modalities of temporality.

That is to say, to proceed by way of a question? This question before the question, which is a question that Derrida inherited from Heidegger, evokes some of the difficult problems to which Derrida always seemed to return: logocentrism, a "metaphysics of presence," and onto-theology to name a few. An evocation of the question before the question puts into question a perception of temporality and being that is grounded in an ontological economy of presence and is, therefore, inextricably bound to the Derridean quasi-concepts of trace, archi-writing, the supplement, the wholly other, and différance: "this trace being related no less to what is called the future than to what is called the past, and constituting what is called the present by means of this very relation to what it is not; what it absolutely is not, not even a past or a future as a modified present" ("Différance" 13). Once we summon the possibility of a question that precedes the question, both a revenant and a messiah emerge (the messiah of the messianic, or the messiah who never

1. I would like to doubly thank Ada Jaarsma for reviewing this paper with such care, attention, and thoughtfulness as well as the anonymous reviewer of this essay for their encouraging and insightful comments. Also, many thanks to Kaitlin Rothberger, Walter Reid, and Kirk Niergarth for commenting on earlier iterations of this paper.

2. From this point on in the essay, I will refer to this essay as "A Certain Impossible Possibility" or "ACIP." 
arrives). ${ }^{3}$ Perhaps, we can preliminarily frame the event as a double session: the (im)possible and unforeseeable "moment" wherein a revenant inhabits its structure from within and a messiah falls vertically upon us.

But we must not forget to emphasize the affirmation of a "yes" before the "yes" that is behind the question. The infamous "yes, yes" that is always a différant yes. Derrida, for example, writes, "we cannot say yes without promising to confirm it and to remember it, to keep it safe, countersigned to another yes; we cannot say yes without promise and memory, without the promise of memory" ("Ulysses Gramophone" 596).4 The second yes always beckons the first, but these yeses repeat themselves différantly, yet to pin down these irreducible differences with a master concept is questionable: "the trace is nothing, it is not an entity, it exceeds the question What is? and contingently makes it possible" (Of Grammatology 47). Here we can name the first pair of many aporias to come: the trace and différance. Both the trace and différance, although not usually characterized as aporias, constitute an impasse that escapes dialectical and rational movements, that is, they both conceptualize a "situation" that cannot be resolved through calculation or reason. The trace and différance, moreover, are not words or concepts (I will take the liberty of extending Derrida's famous quotation that différance is "neither a word nor a concept" ["Différance" 7] to the "quasi-concept" of the trace); rather, they make words and concepts possible. Nevertheless, the trace and différance, of course, cannot be conceived of as master terms, as they are constituted by a differential, double-marking, which is an idea that arises out of Ferdinand de Saussure's structural linguistics that posits the now infamous twofold thesis concerning the concept of the linguistic sign: the arbitrariness of the sign and the differential relation of language. ${ }^{5}$ The trace and différance, moreover, cannot be limited to signs, since the trace writes to the residual play of differences (differing and deferring), which confounds the notion of an originary moment and undermines the metaphysical gesture of compartmentalizing presence and absence. There is always, then, the trace of an absent-present other. Thus, the aporia can be defined as the ways in which the trace and différance are the conditions of possibility for signification, but are simultaneously the impossibility of naming the conditions of possibility within an onto-theological and originary field: "this unnameable is the play which makes possible nominal effects, the

3. One should, of course, mark the difference between messianicity and messianism. Put simply, messianism in the Judeo-Christian-Islamic traditions calls for a messiah with particular characteristics who will arrive in a particular spatio-temporal location, whereas the messianic, for Derrida, is a call for the other that is always deferred-to "come." The messiah, in this case, cannot be predicted in advance, and thus never arrives: "this strange concept of messianism without content, of the messianic without messianism" (Specters of Marx 82). In other words, the messianic actively waits for the other, which subverts the categories of traditional and theological messianisms of the past, so much so that the other's qualities and traits cannot be determined or anticipated; thus, the messianic is a "messianism without content."

4. It could be said that no one understands the intersections of promise and memory-on the violence of rendering one calculable-more than Nietzsche: "the task of breeding an animal that is permitted to promise includes, as condition and preparation, the more specific task of first making man [sic] to a certain degree necessary, uniform, like among like, regular, and accordingly predictable [...] with the help of the morality of custom and the social straightjacket man [sic] was made truly calculable" (36).

5. Saussure on the arbitrary nature of the sign: "The bond between the signifier and the signified is arbitrary. Since I mean by sign the whole that results from the associating of the signifier with the signified, I can simply say: the linguistic sign is arbitrary (67). Saussure on the differential relation of the sign: "Within the same language, all words used to express related ideas limit each other reciprocally; synonyms like redouter 'dread,' craindre 'fear,' and avoir peur 'be afraid' have value only through their opposition" (116). 
relatively unitary and atomic structures that are called names, the chains of substitution of names in which [...] the nominal effect différance is itself enmeshed, carried off, reinscribed, just as a false entry or a false exit is still part of the game, a function of the system" ("Différance" 27). These quasi-concepts are beyond their own possibilities. The event, I will contend, is also beyond its own possibility, so much so that the event surprises and tears the fabric of possibility, but I will refrain from discussing the event in any great detail, for a detour is necessary before we commence.

It should be noted, however, that unveiling a thesis, that is to say, a carefully-crafted preface, to the reader that feigns the ability to present a cohesive truth in an unproblematic manner is antithetical to any rendering of the event, as the event must be singular and unanticipatable-beyond all calculation-and thence, the very logic of the text, if it is to constitute, "speak," and address the (im)possibility of writing "the" event, must exceed a formulaic and mechanistic approach on the level of composition. It would, therefore, be unfaithful to the event if I were to read and relay the event with a calculative method; rather, I wish to position the event as a moment of both contamination and contingency, so I will refrain from giving an axiomatic "account" of the event.

At this point, before we have considered the event, I would like to briefly acknowledge a certain difficulty that presents itself upon reading the "introductory" remarks of most of Derrida's texts, which demonstrates the anxiety of effacing a certain understanding of the event through the act of summarizing the "key points" of an essay beforehand:

the most consistently difficult sections of Derrida's texts are his "prefatory" remarks [...] his prefaces [...] especially mark that which makes a text explode the classical ideas of truth and presence. And they must do so without letting the preface anticipate this "conclusion" as a single, clear, luminous truth. Thus the complication of these prefaces. One way of complicating a preface is to leave as a knot that which will later become several strands ("Force and Signification" TN 3).

It seems, then, that Derrida's commitment to the nuances and complications of introducing, simplifying, and reducing is a fear of annulling the event through the act of anticipation. So I cannot "promise" where this text will ultimately lead if I desire to think meaningfully about the event. Moreover, there is a certain danger that arrives upon uttering the word "event," since the event to an extent resists theorization: "that an event took place that cannot under any circumstance be reduced to its analysis, an event that cannot be reduced to any saying. It's the unsayable: the dead, for example, the dead" ("ACIP" 460). That is not to say, though, that one cannot "say," "make," or "write" the event, nor does an engagement with the event lead to negative theology, but I will leave these thoughts open for the time being. I would like to maintain, furthermore, that there is a way to write (im)possibly about the event, or why else would I take up the project of writing about the event? Nevertheless, we must take seriously Derrida's advice that a promise is always a threat, so there is always a possibility that this promise, my promise, could fail, but to continue on in this way would be contrary to the event. 


\section{Sealing the Event: \\ Defeating the Performative and the Constative in the Name of Perverformativity}

In the concluding paragraphs of "A Certain Impossible Possibility," Derrida says that "a pure event, worthy of the name, defeats the performative as much as the constative. One day we'll have to come to terms with what this means" (460). In this section of the paper, my concern will be to come to terms with what it means for the event to "defeat" both the constative and performative utterances; however, in order to take up Derrida's claim sincerely, a solicitous reading of J.L Austin's How to Do Things With Words must be undertaken. I will proceed with the aforementioned task in what follows.

Austin, as is well known, distinguishes between two general categories of utterances in How to Do Things With Words: the constative and the performative. First, Austin describes constative utterances, which can be understood best as statements that describe a state of the world through representation, and thus can be either true or false. The constative utterance, moreover, is an example par excellence of how language has been conceived by philosophers in the Western philosophical tradition. Second, the performative utterance, according to Austin, must satisfy the following conditions:

a. they do not 'describe' or 'report' or constate anything at all, are not 'true or false'; and

b. the uttering of the sentence is, or is a part of, the doing of an action, which again would normally be described as saying something (5).

The performative utterance, then, can be neither true nor false and "allows us to do something by speech itself," that is to say, the act of speaking itself is transformative in one way or another, and therefore is not intelligible as either "true" or "false," since the utterance itself is performing an action ("Signature Event Context" 321). For instance, Austin uses the example of naming a ship to exemplify the performative utterance: "I name this ship the Queen Elizabeth' - as uttered when smashing the bottle against the stem" (5). It could be said, then, that, for Austin, the performative utterance is doing and performing something to the "world," while the constative utterance merely reports and describes the "world"; nevertheless, both categories are still communicative, as Derrida points out: "this category of communication [the performative utterance] is relatively original. Austin's notions of illocution and perlocution do not designate the transport or passage of a content of meaning, but in a way the communication of an original movement (to be defined in a general theory of action), an operation, and the production of an effect" ("Signature Event Context" 321). To use Austin's example, when one says, "this ship is named the Queen Elizabeth," one is merely reporting the name of a ship; therefore, this could be categorized as a constative utterance. On the other hand, a performative utterance such as "I name this ship the Queen Elizabeth" mobilizes language so that it does something, that is, the performative produces effects; namely, how we understand the ship in itself. On these grounds, the ship is now named the Queen Elizabeth. However, the performative utterance can fail, so there must be an appropriate "context" for a performative utterance to "fire." i.e., specific conditions have to be met for the ship to really take on the name Queen 
Elizabeth. Not everyone, for instance, is eligible to name the ship. We will explore the place of the performative in relation to context below.

Once again, the performative utterance cannot be true or false. Austin circumvents the notion that performative utterances can be interpreted as either being true or false with the example of the promise:

do we not actually, when such intention is absent, speak of a 'false' promise? Yet so to speak is not to say that the utterance 'I promise that...' is false, in the sense that though he [sic] states that he does, he doesn't, or that though he describes he misdescribes misreports. For he does promise: the promise here is not even void, though it is given in bad faith. His utterance is perhaps misleading, probably deceitful and doubtless wrong, but it is not a lie or a misstatement (11).

The promise is undoubtedly still a promise even if it turns out to be insincere, viz., I can promise that I will meet you tomorrow, and even if I do not show up tomorrow, then the promise is still a promise. What is more, the utterance is neither "true" nor "false" like the constative variation of the sentence would be, e.g., I promised you yesterday that I would be there. The foregoing example of the promise begs a qualification of the conditions of possibility for the performative utterance to "fire," as many things can go wrong during the "firing" of the performative utterance, which invalidate the utterance, so much so that the utterance is "disallowed" or "botched." Hence, the performative is "void or without effect" (Austin 17). In this case, the "failed" performative utterance can be "infelicitous" or "unhappy." Austin formulates six, albeit tenuous, categories to classify "unhappy" utterances, which fall under the aegis of "The Doctrine of the Infelicities." Unhappy utterances, for Austin, have no effect. There are misfires (acts purported but void), which extend to misinvocations (acts disallowed (misapplications)) and misexecutions (acts vitiated (flaws and hitches)), and abuses (acts professed but hollow (insincerities)) (Austin 11). Austin develops three subsequent terms for understanding speech acts: the locutionary act, the illocutionary act, and the perlocutionary act. Austin writes, "we distinguished the locutionary act (and within it the phonetic, the phatic, and the rhetic acts) which has a meaning; the illocutionary act which has a certain force in saying something; the perlocutionary act which is the achieving of certain by saying something" (121). In other words, the locutionary act is a statement's ostensible meaning regarding its syntactical, grammatical, and semantic content, while the illocutionary act is the intended meaning (force) of the utterance. The perlocutionary act, simply enough, is the actual effect of the speech act regardless of the utterance's illocutionary force. An unhappy utterance, according to Austin, will unquestionably yield an illocutionary force, but will not deliver the "intended" perlocutionary effect.

In "Signature Event Context," Derrida advances two critiques of Austin's speech act theory as outlined in How to Do Things With Words. First, Derrida problematizes the demarcation between the performative and the constative. Second, Derrida undermines Austin's privileging and separation of "serious" from "non-serious" speech acts, i.e., the "parasitic" and "abnormal" cases of language. The latter critique of Austin is beyond the 
scope of this essay, while the former is central for establishing Derrida's claim that the event occurs, if it occurs at all, "outside" of performative and constative utterances.

Derrida's contention that Austin's speech-act theory presupposes an absolute and originary presence that has the capacity to determine in advance the totality of context is at odds with the iterability of the sign: "every sign, linguistic or nonlinguistic, spoken or written [...] as a small or large unity, can be cited, put between quotation marks; thereby it can break with every given context, and engender infinitely new contexts in an absolutely nonsaturable fashion" ("Signature Event Context" 320). In a word, iterability, for Derrida, is the assertion that a sign is only possible because of its capacity to be reproduced, that is, the ways in which the sign is only intelligible if it is repeatable, quotable, and citable, which necessitates a fundamental absence from within the sign. An utterance's perlocutionary force cannot be directed or calculated in advance, since the structure of the utterance hinges upon transgressing its own limit through a repetition of difference. The iterability of the sign, then, is caught in an aporetic movement wherein it is both impossible and possible to make the "sign" generalizable and unique. The question becomes: is this "sign" merely a repetition of the ideal "sign," or is this "sign" a "sign" that is unique and singular in its own way?

Iterability, moreover, opens up a space for difference to emerge, since a sign-and I mean "sign" in the broadest sense of the term-can enter a myriad of unanticipatable contexts and take on divergent meanings. Derrida observes, "Austin's analyses permanently demand a value of context, and even of an exhaustively determinable context, whether de jure or teleologically; and the long list of "infelicities" of variable type which might affect the event of the performative always returns to an element of what Austin calls the total context" ("Signature Event Context" 322). Austin's project, for Derrida, is suspect for policing the context through an analytics of the utterance that outline the conditions for a performative utterance to fire felicitously. If the event is to be theorized as an event insofar as it is unforeseeable, this complete saturation of context has perilous consequences for the event, because if the event is dependent upon a certain impossibility of calculation, then the supposition of a stable ipseity that commands the performative utterance completely without hindrance prohibits the possibility of the event, since the "pure" performative only takes place within a field of self-presence and possibility. The event, on the contrary, demands the impossible. Austin's attestations of what constitutes the "right" and "present" context is untenable once we view speech acts through the lens of iterability, for the illocutionary and perlocutionary forces of the utterance can never be completely known in advance. Absence is at the heart of the sign. The "purity" of the speech-act and the speaker's assumed and "present" ability to govern meaning in a carefully controlled way-an assertion that denies dissemination-in Austin's system collapses: "the conscious presence of the speakers or receivers who participate in the effecting of a performative, their conscious and intentional presence in the totality of the operation, implies teleologically that no remainder escapes the present totalization" ("Signature Event Context" 328). Can a context ever be fully determined? Is it possible to claim that one can anticipate the contours of context? There is always a flickering of an absent-presence on the part of the addressee and the sender, which marks a dehiscence within the mark itself: a mark that absconds the determinable: "no context can enclose it. Nor can any code, the code of being here both the possibility and impossibility of writing, of its essential iterability (repetition/alterity)" ("Signature Event Context" 317). In short, 
Austin's account of the performative utterance leaves no room for the double play (differing and deferral) of différance. Let us remember, though, that the demarcations between the performative and the constative utterances are not as distinct and different from one another as the preceding definitions imply, of which Austin was cognizant; ${ }^{6}$ however, this will become much clearer below.

There is another point that is important to note with regard to Austin's speech-act theory, which is helpful for conceptualizing the event; namely, the ways in which Austin isolates the conditions of possibility for the performative utterance to fire from its conditions of impossibility, e.g., Austin's "Doctrine of the Infelicities." "Austin does not ask himself what consequences derive from the fact that something possible-a possible riskis always possible," Derrida cautions, is somehow a necessary possibility. And if, such a necessary possibility of failure being granted, it still constitutes an accident. What is a success when the possibility of failure continues to constitute its structure? ("Signature Event Context" 324). In other words, the actual structural possibility of the firing of the performative is its possible failure, which leads to the impossibility of a pure performative utterance. Hence, the excluded - the possibility of the utterance's failure-haunts the very act of firing. Austin's "Doctrine of the Infelicities" is founded upon an exclusion, as the failure of the performative cannot be conflated with its very possibility, since the infelicitous performative is an aberration, a failed performative, and exists outside the category of the performative; thus, it is not constitutive of a "pure" or "ideal" performative. It could be said, then, that Austin is only concerned with the possibility of the performative's failure externally, that is, as a threatening phenomenon that exists outside or before the utterance, whereas Derrida is speculating on the performative utterance's possibility to (mis)fire from within its very structure. ${ }^{7}$ For Derrida, the misfiring of a performative utterance is also its grounds for success, i.e., the structural possibility of the firing of the performative will always be caught up with its possible failure, and the possibility of its failure haunts the very act of its ability to fire. There is always already a spectre, a possible-impossible failure, because there needs to be an understanding of failure in order for one to conceptualize a success, so it could be written that failure does not exist on the outside, but on the inside. Although, it should be remembered that the "inside" and the "outside," for Derrida, should also be troubled, so a simple division

6. Austin, for instance, writes, "Because we suggested that the performative is not altogether so obviously distinct from the constative-the former happy or unhappy, the latter true or false-we were considering how to define the performative more clearly" (67). See Shoshana Felman's The Scandal of the Speaking Body: Don Juan with Austin, or Seduction in Two Languages for an exciting exploration of these reflections. Felman illustrates the collapse between the constative and performative distinction when she writes, "But this criterion is insufficient, for we find other expressions that do not include an explicit performative verb and yet still belong to the category of the performative because they too accomplish an action and lie outside the reach of the truth/falsity criterion" (7).

7. It is interesting to note the potential tension between Felman's and Derrida's respective readings of Austin. Felman compares Benveniste and Austin, "Now for Austin, the capacity for failure is situated not outside but inside the performative, both as speech act and as theoretical instrument. Infelicity, or failure, is not for Austin an accident of the performative, it is inherent in it, essential to it" (45). These differences, nonetheless, cannot be elaborated upon here. 
between the two is not viable. ${ }^{8}$ The performative, however, is perverse; thus, it is no longer a performative, but a perverformative. ${ }^{9}$

Derrida asks the question: "would a performative utterance be possible if a citational doubling [doublure] did not come to split and dissociate from itself the pure singularity of the event?" ("Signature Event Context" 328). The pure singularity of the event, perhaps, can be traced through to the final section of "Signature Event Context" wherein Derrida writes of the signature, as the signature, like the event, is caught in the interstices of both absence and presence and the general and the particular, for the signature is a mark of singularity, and maybe even an event, yet it is only possible because of a repetition of differences: "a truth that is nothing other than its own truth producing itself, this is indeed a unique event; but it is also a machine and a general truth" ("Psyche" 216). The signature's reproducibility-its inscription and seal-make the singularity of the signature a possibility: "the condition of possibility for these effects is simultaneously, once again, the condition of their impossibility[...] In order to function, that is, in order to be legible, a signature must have a repeatable, iterable, imitable form: it must be able to detach itself from the present and singular intention of its production" ("Signature Event Context" 328). Many interesting and useful questions, I think, begin to take flight when we juxtapose the aporia of the signature and the possible impossibility of the event. Is the event contingent upon a series of citations, repetitions, and iterations? And can we write that the event is iterable? The event is certainly singular and unique, but is it possible to posit(ion) the event so it exceeds the repetitions that make the signature an (im)possibility? If we characterize the event as a moment that exceeds the trace and différance, then we risk thinking of the event as a moment of presence and transcendence, for the event, too, must be ruptured upon its own revealing. Derrida writes:

I was saying before that the saying of the event presupposed some sort of inevitable neutralization of the event by its iterability, that saying always harbors the possibility of resaying. A word is comprehensible only because it can be repeated; whenever I speak, I'm using repeatable words and uniqueness is swept into this iterability. Similarly, the event cannot appear to be an event, when it appears, unless it is already repeatable in its very uniqueness. It is very difficult to grasp this idea of uniqueness as immediately iterable, of singularity as immediately engaged in substitution, as Levinas would say. Substitution is not simply the replacement of a replaceable uniqueness: substitution replaces the irreplaceable. The fact that, right away, from the very outset of

8. Pheng Cheah expresses this well when he writes:

Derrida warns us that this exteriority must not be thought in simple opposition to the inside. A simple outside is complicit with the inside...From a dialectical standpoint, the outside qua object is the negation of the inside qua subject. But it can be negated in turn when the outside is recognized by the subject as nothing other than itself thereby allowing it to return back to itself in a moment of reflective internalization. (74)

9. Derrida introduces this neologism in The Post Card: From Socrates to Freud and Beyond: "Here is the master of the perverformative" (136). 
saying or the first appearance of the event, there is iterability and return in absolute uniqueness and utter singularity, means that the arrival of the arrivant - or the coming of the inaugural eventcan only be greeted as a return, a coming back, a spectral revenance ("ACIP" 452).

The event will be neutralized and effaced if it is taken as a moment of pure presence that is not disrupted by both a trace of the past and the possibility of future iterations. The event, even though it is singular and unsubstitutable, is immediately ensnared in a space of replacement. The only way, for Derrida, to respond to this this spectral revenance-a Nietzschean return-can also be found in the logic of the perverformative wherein the possibility of the perverformative is always haunted by its failure: "my relationship to the event is such that in the experience that I have of the event, the fact that it will have been impossible in its structure continues to haunt the possibility" ("ACIP" 452). And here we can begin to make some more concrete connections. The problem that I identified earlier with Austin's hypothetical speaker, regarding the pure presence of the "subject" who controls the context and excludes aberrations via the "Doctrine of the Infelicities" necessitates a smooth transitioning between the illocutionary and perlocutionary utterances. In other words, the speaker's intentions are immediately accessible and anticipatable, so the performative, if conceptualized in this way, leaves no room for contingency, since it depends on outcomes a priori, e.g., the performative "I do" uttered during the wedding, if all conditions are met, will result in marriage. However, it could be said that this was already calculated through a foreclosing of context, and therefore it is in no way constitutive of an event.

If the event is indeterminable, then it cannot be performative, since the "pure" performative is a category of utterance that privileges and anticipates an outcome-the force of the speaker's intended meaning yields specific effects that deny the possibility of the event, for the event cannot be calculated beforehand. Thus, the event, if it is to be worthy of the name, must bypass the categorical distinction of the performative and the constative. The constative, for obvious reasons, is not constitutive of the event because the constative utterance merely relays information and represents the "world." Only the failed performative, the perverformative, can be attributed to an event worthy of the name. To be specific, the event must defeat the distinction between the performative and the constative.

I have maintained Austin's distinction between the performative and the constative to demonstrate that if one can predict formulaically the perlocutionary force of an utterance via the illocutionary utterance, then it is not, cannot, be named an event. However, if we take into account Derrida's claims concerning context and iterability, especially the ways in which the sign, for Derrida, cannot ever fully be saturated by a fixed meaning or context before the deployment of the utterance, and the possible impossibility of the event with relation to a specific conception of the graphematic exceeds the presence of the sign, then it follows that the very threads of the distinction between what is performative and constative, for Austin, fails. It is, we could say, infelicitous! Hence, it seems that every perverformative has the capacity to yield an event, which is bound to the threat of failure-the absent-presence that permeates and conditions signification from within its very structure-and is subsequently integral to an understanding of the event. 


\section{Aporias: Taking A(c)count of the Event}

My concern in this section is to briefly illustrate some of possible-impossible aporetic "events" that turn up throughout Derrida's work; specifically, the decision, forgiveness, and invention. I intend to think through the deconstructive logic of the aforementioned aporias to avoid the ostensible privileging of the linguistic and semiological registers in the preceding section, even though the basic theoretical suppositions and movements of "the conditions of possibility are also the conditions of impossibility" will be sustained.

To begin with, the aporia is central to Derrida's quasi-transcendental philosophy. I would like to take the time to tease out the term quasi-transcendental philosophy because, I think, it is possible to understand this term in two ways. The term, on the surface, evokes other transcendental philosophies such as Immanuel Kant's transcendental idealism and Gilles Deleuze's transcendental empiricism; nevertheless, these three transcendental philosophies are irreconcilable. ${ }^{10}$ Kant, however, uses the term transcendental in a very specific way, as he contrasts the transcendental with the transcendent.11 For Kant, the transcendental is the underlying conditions of possibility for experience and knowledge whereas the transcendent is beyond what one can know and experience. I would like to keep both terms as Kant used them intact. Derrida's philosophy, perhaps, can be said to be both quasi-transcendental and quasi-transcendent. Length restrictions limit me from completely exploring these contentions; however, I will do my best to succinctly state the case in both instances.

First, Derrida's quasi-transcendental philosophy works within the conditions of possibility while also seeking out the conditions of impossibility, so it could be said quite easily that Derrida always seems to reach an impasse where an aporia dawns that is at once impossible and possible. I will not expand upon this point, since it is generally

10. See Gilles Deleuze's "Immanence: A Life" for a clear explication of the term "transcendental empiricism." Deleuze writes, "it can be distinguished from experience in that it doesn't refer to an object or belong to a subject (empirical representation). It appears therefore as a pure stream of a-subjective consciousness, a prereflexive impersonal consciousness, a qualitative duration of consciousness without a self" (25). Also, see Claire Colebrook's Gilles Deleuze for another helpful explanation of the term: "Philosophy can only be a transcendental empiricism if it does not set up some foundation outside experience. Experience cannot be grounded on man, the subject, culture or language. There is just an immanent flow of experience from which distinct beings, such as human subjects are formed" (89). See, moreover, "The Transcendental Aesthetic" in Immanuel Kant's Critique of Pure Reason for Kant's conceptualization of transcendental idealism.

11. Kant notes:

Hence, transcendental and transcendent are not the same. The principles of pure understanding we presented above should be only of empirical and not of transcendental use, i.e., of a use that reaches beyond the boundaries of experience. But a principle that takes away these limits, which indeed bids us to overstep them, is called transcendent. If our critique can succeed in discovering the illusion in these supposed principles, then those principles that are of merely empirical use can be called, in opposition to them immanent principles of pure understanding. (386) 
accepted that Derrida's work is quasi-transcendental. ${ }^{12}$ The case for the quasitranscendence in Derrida's thought is, nevertheless, harder to argue. It seems that the messianic call of the to-come fits the paradigm of what we might want to call quasitranscendence, since the messianic is a call for a messiah that will never arrive, and even if she were to arrive, we would have to ask: "when will you arrive?" Derrida's messianic call is arguably quasi-transcendent, as it defers the arrival of the messiah while situating the messiah in a space that is always to-come. The messiah is not transcendent in the sense that she is completely beyond knowledge or experience like Kant claims, as the messianic call is both absent and present; rather, she opens up the possibility for a future without reserve or limit without elevating the messiah to a position of complete transcendence that would instantiate an onto-teleo-theology wherein a first cause, being, or telos is installed.

The messianic, like the event, is always already open to the unanticipatable. Perhaps it could be argued that Derrida's quasi-transcendence is the only way out of a certain Levinasian problem of the Other, which could be formulated as follows: if we conceptualize the Other from a space of radical alterity, then we are doing violence to the Other through omission, so much so that it is as if the Other has been effaced through negative theology. If we bring the Other into a discursive framework, however, then the Other is also subject to violence, for the Other is negated through a return to the Same. Simply put, the absolute alterity of the Other is effaced if one chooses to address the Other, or place the Other on the "outside."13 Derrida's quasi-transcendence, if it can be labelled as such, possibly obviates both of these problems, for it destabilizes a conception of the Other that is still wholly other-a radical alterity is upheld - while still writing of an affirmation that is foreign to all dialectics, a possibility of alterity without negation, an Other who defers sublation (Aufhebung), an Other without an onto-theological return. I unfortunately do not have time to follow up on these tentative and digressive claims, but these questions will undoubtedly float around during the following discussion. ${ }^{14}$

Derrida makes two elliptical references to the decision by way of Søren Kierkegaard in two texts. First, the epigraph of Derrida's famous essay on Michel Foucault's History of Madness entitled "Cogito and the History of Madness" begins with an epigraph on the decision: "The Instant of Decision is Madness" (32). Also, in The Gift of Death, Derrida evokes the same line:

12. See Richard Rorty's essay “Is Derrida a Quasi-Transcendental Philosopher?” and Andrea Hurst's essay "Derrida's Quasi-Transcendental Thinking" for critical inquiries into the status of Derrida as a "quasitranscendental" philosopher.

13. See Derrida's famous essay “Violence and Metaphysics” wherein he explicitly addresses Levinas' project. 14. My argument that Derrida is a quasi-transcendent philosopher flies in the face of Pheng Cheah's recent reading of Derrida where he argues for a deconstructive materialism. This essay does not have the time or space to address this debate, but a quasi-transcendent and a deconstructive materialist understanding of Derrida both attempt to wrest Derrida's project away from the traditional categories of idealism and materialism. To simplify, it all hinges on how one reads the word "alterity" in Derrida's work. See Daniel Smith's essay entitled "Deleuze and Derrida, Immanence and Transcendence: Two Directions in Recent French Thought," which explores the relationship between Derrida's thought and transcendence while also reflecting on the intersections of Derrida's and Deleuze's philosophies. 
I have underlined the word instant: "the instant of decision is madness," Kierkegaard says elsewhere. The paradox cannot be grasped in time and through mediation, that is to say in language and through reason. Like the gift and "the gift of death," it remains irreducible to presence or to presentation, it demands a temporality of the instant without ever constituting a present. It belongs to an atemporal temporality, to a duration that cannot be grasped: something one can neither stabilize, grasp [prendre], apprehend, or comprehend. (66).

There are a number of fascinating moments in the preceding passage. Notably, the evocation of an atemporal temporality squares with the aporetic impossible-possibility of the event that exceeds "language" and "reason", so the decision, if it is to be a decision, must break with the limits of the "reasonable," because if one adheres to a set of outcomes, calculations, or precedents, then the decision is already predetermined, and therefore the decision has not taken place. Temporality, then, is suspended in this leap-this instant-of madness that is beyond knowledge. The decision like the event, then, contests modalities of temporality, as the decision does not take place within time-time is suspended, ungraspable, (im)possible. The possible becomes impossible, and the impossible becomes possible.

Derrida makes a similar claim regarding the aporia of forgiveness: "forgiveness is not, it should not be, normal, normative, normalising. It should remain exceptional and extraordinary, in the face of the impossible: as if it interrupted the ordinary course of historical temporality" (On Cosmopolitanism and Forgiveness 32). Forgiveness, like the decision, arrests time. Forgiveness, of course, has not occurred if one forgives within an economy of calculation that weighs out what is forgivable and what is not. If the forgivable is already determinable in advance-if one can already forgive-then the conditions of possibility for forgiveness were already in place, which precludes forgiveness, so one must forgive the unforgivable, which requires one to disturb the course of historical time, for forgiveness must go beyond-exceed-the possible. Forgiveness is an impossible possibility.

The third rupture concerns the aporia of invention: "indeed there will be no invention here today unless that break with convention, into impropriety, is made; in other words, that there will be invention only on condition that the invention transgress, in order to be inventive" ("Psyche" 216). An invention is not an invention unless it goes beyond what is intelligible, that is, the invention must "transgress" current capacities and possibilities. If one "creates" what is already possible, then an invention has not occurred; nonetheless, the only way to place this conception of invention is outside of a dialectical movement, the Hegelian labour of preservation and negation wherein inventions are hailed back into the logic of the Same. But does the invention have to become part of a discourse itself after its creation? The only way to answer this question, which is definitively a question of the event, is to return to the disruption of temporality. The decision, invention, and forgiveness, are all (im)possible events. They are instants that exceed, overflow, and rupture what is already possible: "one of the characteristics of the event is that not only does it come about as something unforeseeable, not only does it disrupt the ordinary course of history, but it is also absolutely singular" ("ACIP" 446). The singularity of the 
event, however, is contaminated at the "origin," for it beckons a return: "it must be a unique experience each and every time for it to be a unique, unpredictable, singular, and irreplaceable event. But at the same time, the repetition of the event must be presupposed, from the threshold of the house and from the arrival of the irreplaceable" ("ACIP" 453). This nondialectizable return is the inaugural possibility for the singularity of the event, that is, an event that is, perhaps like the signature, at the same time the impossibility of eventhood. The event, if it is to be worthy of the name, must go beyond the limits of the constative and performative, the present and the absent, the general and the particular. On the one hand, the event must remain unpredictable; therefore, the event exceeds a plane of horizontality and falls upon us vertically like a gift, because if I can already predict, or am prepared to host the event, then the event has not occurred: "it means that the event as event, as absolute surprise, must fall on me" ("ACIP" 451). On the other hand, the event's possible impossibility is haunted by a spectre, as we saw with the perverformative, which constitutes the structure of the event from within. Consequently, the event is both a revenant and a messiah of messianicity. In any case, the event is unforeseeable, absolutely singular, and destabilizes both temporality and historicity.

\section{The Event as Secret: Faith Beyond Knowledge}

I began this essay by gesturing toward a troubling question: is writing the event possible? In other words, the (im)possibility of writing the event will always be caught up in the problem of the nameable, which can be understood in two ways. First, the question never depends on the question as such, but what conditions are in place to be able to ask the question, i.e., what are the spectral conditions that have been forgotten from the question, but are still integral to the framing of the question (the yes that is in place before the yes). Second, there is the problem of naming, locating, and ontologizing these questions, these remains. However, these questions always operate on the borders of the possible and the impossible, the absent and the present, and the intelligible and the unintelligible.

But, to be sure, I intend to keep my promise, so I will speak to the notion of writing the event, and then address the symptom and the secret, both of which my title promises, but I have thus far repressed.

I am anticipating...calculating...

In an early essay entitled "Force and Signification," Derrida writes, "it is because writing is inaugural, in the freshest sense of the word, that it is dangerous and anguishing. It does not know where it is going, no knowledge can keep it from the essential precipitation toward the meaning that it constitutes and that is, primarily, its future" (11). The force of writing-of the sign - to perforate the limits of the impossible is inscribed within its own possibility, as the danger and anguish of the glyph cannot be foreseen. I do not wish to belabour this point, but the word "knowledge" in the foregoing passage provokes the event. Perhaps this beyond knowledge even calls the event. We can stake two claims, then, of this writing of the event. First, writing is always necessarily beyond itself, as it is constituted by its (im)possible capacity to break with context, i.e., iterability. Second, writing must surpass the realm of the calculable, for if we were able to impose a limit that would curb the dissemination of the word, then it would not be writing. This dialogue on 
the possible impossibility of writing the event, I think, brings us closer to the impossibility of a pure event. Writing can only affirm difference and dissemination because it is repeatable, and as such it is ensnared in a general economy: "[the event] must be a unique experience each and every time for it to be unique, unpredictable, singular, and irreplaceable...But at the same time, the repetition of the event must be presupposed from the threshold of the house and from the arrival of the irreplaceable" ("ACIP" 453). Writing takes place within the calculable, but simultaneously suspends calculation. And, to be sure, there is an opening here between the singularity of the event and the originary corruption of the event. We could, however, ask: does writing the event always come after the event? In other words, to write of the event requires that the event has already occurred; hence, one reflects upon the event from a distance, but is it possible to claim that writing the event can spur on another event? Writing, like the event, breaches the limits of knowledge, so to what extent does writing open us up to the other whom we have yet to fully evoke?

The answer to the preceding question, if it can be found, is definitely related to the secret of the event: "whenever the event resists being turned into information or into a theoretical utterance [...] the secret is on the scene [...] The secret belongs to the structure of the event" ("ACIP" 456). The secret is faith beyond knowledge, and the event's possibility is grounded by an opening that can never be foreclosed. The event cannot be an event if the secret is not integral to its structure. The event has to be a surprise; thus, there must be a secret that exceeds knowledge, truth, discourse, time, and history for the event to occur, but the secret is never revealed upon the occurrence of the event, yet that is not to assert that the secret is "hidden." Rather, the secret does not show its face (this is where the messianic, quasi-transcedental aspect of Derrida's reading of the event presents itself most obviously). There, moreover, is only a symptom-a symptomatology-which should not be conflated with the symptom of Freudo-Lacanian discourses. The symptom, for Derrida, has never been repressed and is not expressed indirectly: "a symptom is something that falls. It is what befalls us. What falls vertically on us is what makes a symptom" ("ACIP" 457). The symptom is similar to an (im)possible gift, which can only be recognized as a gift if it reaches past an economy of exchange that is devoid of rules and calculations, so the symptom is what arrives with the event and is coterminous with a certain Nietzchean perspectivism, as once there are axioms, codes, rules, and plans, then the event is no longer possible. The symptom, then "is a signification of the event over which nobody has control, that no consciousness, that no conscious subject can appropriate or control" ("ACIP" 457). The decision, the gift, the event, invention, etc. always come from the other, for the other, and, like justice, do not wait, for the event is an arrival that one could never prepare for. And, perhaps here, beyond the dialectic, is where the difficult thinking begins. 
Works Cited

Austin, J.L. How to Do Things With Words. Cambridge: Harvard University Press, 1962. Print.

Cheah, Pheng. "Non-Dialectical Materialism." New Materialisms: Ontology, Agency, and Politics. Ed. Diana Coole and Samantha Frost. Durham: Duke University Press, 2010. 70-91. Print.

Colebrook, Claire. Gilles Deleuze. London: Routledge, 2002. Print.

Deleuze, Gilles. "Immanence: A Life." Pure Immanence: Essays on A Life. Trans. Anne Boyman. New York: Urzone, 2001. Print.

Derrida, Jacques. "A Certain Impossible Possibility of Saying the Event." Trans. Gila Walker. Critical Inquiry 33.2 (2007): 441-461. Print.

- - — "Cogito and the History of Madness." Writing and Difference. Trans. Alan Bass. Chicago: Chicago UP. 1978. 31-63. Print.

____. "Différance" Margins of Philosophy. Trans. Alan Bass. Chicago: Chicago UP, 1982. 1-27. Print.

- - —. "Force and Signification." Writing and Difference. Trans. Alan Bass. Chicago: Chicago UP. 1978. 3-30. Print.

———. The Gift of Death. Trans. David Wills. Chicago: Chicago UP, 1999. Print.

- - - Of Grammatology. Trans. Gayatri Chakravorty Spivak. Baltimore: Johns Hopkins UP, 1976. Print.

- - - On Cosmopolitanism and Forgiveness. Trans. Mark Dooley and Michael Hughes. New York: Routledge, 2001. Print.

- - - The Post Card: From Socrates to Freud and Beyond. Trans. Alan Bass. Chicago: Chicago UP. 1980. Print.

- - - "Pysche: Inventions of the Other." Trans. Catherine Porter. A Derrida Reader: Between the Blinds. Ed. Peggy Kamuf. New York: Columbia UP. 1991. 201-220. Print.

- - - "Signature Event Context." Margins of Philosophy. Trans. Alan Bass. Chicago: Chicago UP, 1982. 307-330. Print.

_-——. Specters of Marx. Trans. Peggy Kamuf. New York: Routledge, 1994. Print. 
- - - "Ulysses Gramophone: Hear Say Yes in Joyce." Trans. Tina Kendall and Shari Benstock. A Derrida Reader: Between the Blinds. Ed. Peggy Kamuf. New York: Columbia UP. 1991. 571-597 Print.

Felman, Shoshana. The Scandal of the Speaking Body: Don Juan with J.L. Austin, or Seduction in Two Languages. Trans. Catherine Porter. Stanford: Stanford University Press, 2002. Print.

Kant, Immanuel. Critique of Pure Reason. Ed. and trans. Paul Guyer and Allen W. Wood. New York: Cambridge University Press. 1998. Print.

Nietzsche, Friedrich. On the Genealogy of Morality: A Polemic. Trans. Maudemarie Clark and Alan J. Swensen. Indianapolis: Hackett Publishing, 1998. Print.

Saussure, Ferdinand de. Course in General Lingustics. Charles Bally and Albert Sechehaye, eds. Trans. Wade Baskin. New York: McGraw-Hill Book Company, 1966. Print. 